\title{
TECTONOPHYSICS
}

Tectonophysics 285 (1998) 333-351

\section{Extensional tectonics in the Caledonides of southern Norway, an overview}

\author{
Torgeir B. Andersen * \\ Institutt for Geologi, Universitetet i Oslo, P.O. Box 1047, Blindern, N-0316 Oslo, Norway
}

Received 24 October 1995; accepted 30 July 1996

\begin{abstract}
The extensional collapse of the Scandinavian Caledonides resulted in rapid tectonic denudation of the orogen, exhumation of high- and ultra-high-pressure metamorphic rocks and provided a structural template for the formation of Devonian supra-detachment sedimentary basins. The geometry and intensity of the extensional deformation show considerable variation vertically in the crustal section as well as horizontally from east to west across the orogen. The most prominent structural feature related to the extension in central-south Norway is the change in the direction of tectonic transport, from the easterly directed nappe translation during the Silurian Scandian Orogeny, to top-westerly directed sense of shear during the extension. The Fennoscandian basement was little affected by extension in the eastern Caledonides. In the west, however, top-to-the-west shear zones are commonly observed in basement windows. Deformation affecting the Cambrian to Late Silurian rocks in the Caledonian foreland developed a typical of foreland fold and thrust belt geometry. Deformation in the foreland was apparently contemporaneous with the extension-related decompression of the high-pressure rocks in the hinterland. Thrusting in the foreland may thus have been driven by gravitational collapse, and as such have important similarities to the foreland-hinterland relationships of the Himalayan-Tibetan region. The basal contacts of the Jotun and other major nappes constitute prominent shear zones in which fabrics related to thrusting have been mostly destroyed by extensional shearing. The high structural levels of the Western Gneiss Region, adjacent to the western margin of the Jotun Nappe, were only moderately affected by the extensional deformation. Consequently, the Proterozoic orthogneiss complexes are generally well preserved in this area. The westernmost and structurally lowermost parts of the Western Gneiss Region have, however, been subjected to extreme overburden during the Caledonian continental collision. Initial, near-isothermal decompression of the high-pressure rocks occurred by non-rotational vertical shortening-horizontal stretching at eclogite- to amphibolite-facies conditions; at a later stage, decompression and cooling from amphibolite to greenschist facies occurred by rotational deformation associated with the large-scale extensional detachments. The initial extensional deformation in the hanging wall of the detachments in western Norway commenced at greenschist-facies conditions, and became progressively more brittle and localised as the complexes were exhumed in the Late Silurian to Middle Devonian. Major syn-depositional normal faults in the hanging wall of the extensional detachments eventually controlled sedimentation in the Devonian supra-detachment basins. (C) 1998 Elsevier Science B.V. All rights reserved.
\end{abstract}

Keywords: extension; eclogites; exhumation; Caledonides; Norway

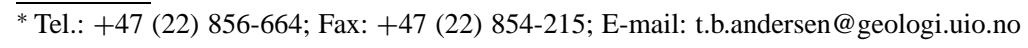




\section{Introduction}

The lower Palaeozoic Caledonian mountain belt in Scandinavia is one of the classical terrains in the study of orogenic products and processes. From the trace of the Tornquist line in the North Sea to the Trollfjord-Komagelv Fault on the Porsanger Peninsula in the northeast, the Scandinavian Caledonides form an approximately 2000-km-long curvilinear belt, broadly comparable in length to the Himalayan mountain belt between the eastern and western syntaxes (Fig. 1). The lower Palaeozoic plate reconstruction, summarised by Torsvik et al. (1996), shows that the Scandinavian Caledonides were facing the similar-sized East Greenland Caledonides after the collision between Laurentia and
Baltica. The preserved width of the Caledonides on-shore south Norway and eastern Greenland is approximately $500 \mathrm{~km}$ and $350 \mathrm{~km}$, respectively. In addition large parts of the hinterland of the orogen occur on the attenuated basement of the shelf areas and continental crust fragments within the North Atlantic (Skogseid, 1994). Although lacking precise Late Silurian palaeogeographical reconstruction, it is clear that the Caledonides of the North Atlantic region including the submerged hinterland regions of the shelves areas, constituted a very large mountain belt similar in size to the present Himalayan-Tibetan region from the frontal thrust in the south to the Tarim basin in the north.

In spite of the widespread extensional deformation affecting the thickened crust in the hinterland of

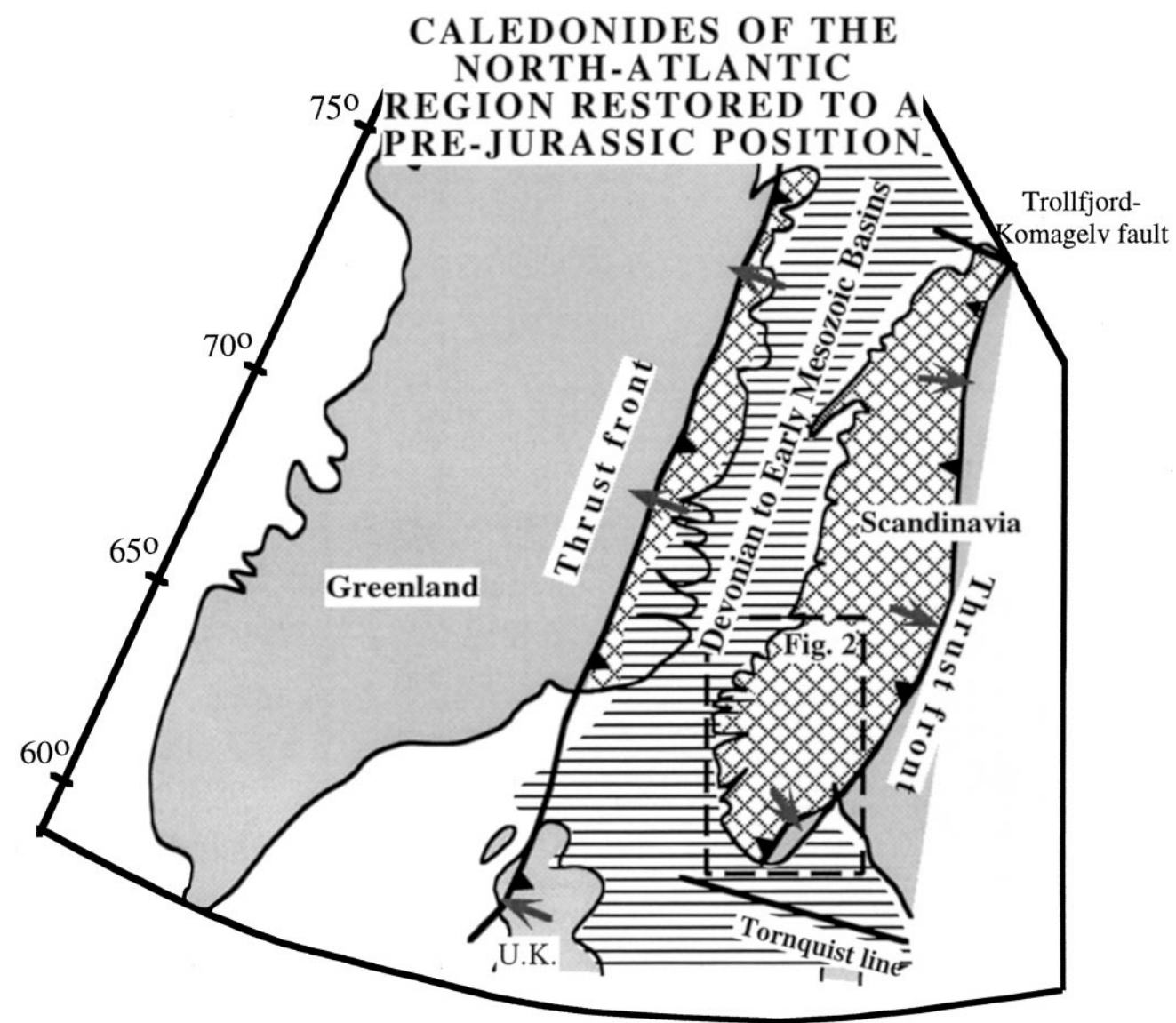

Fig. 1. Pre-Jurassic reconstruction (modified after Skogseid, 1994) of the Caledonides (square pattern) in the North Atlantic region. The map shows location of the study area in southern Norway. Note that the shelf areas and major parts of the onshore regions have been subjected to pre-Jurassic extension. 
the mountain chain during the extensional collapse and throughout the late Palaeozoic, the Caledonides of the North Atlantic region essentially remained a positive topographic element throughout the late Palaeozoic and early Mesozoic (Ziegler, 1988).

Historically, the Scandinavian Caledonides have been particularly important because of the spectacular development of thin, far-travelled and aerial very extensive thrust nappes. Although the product of a polyphase orogenic development, it is generally agreed that the present 'layer-cake' tectonostratigraphy (Roberts and Gee, 1985) was finally assembled and emplaced onto the Fennoscandian Shield basement and cover rocks during the continental collision between Baltica and Laurentia in the middle to Late Silurian referred to as the Scandian phase of the Caledonian Orogeny. Extensional structures in southern Norway are primarily identified by a general reversal in polarity of deformation. The Scandian contraction was associated with southeast-directed structures and nappe transport, whereas the extension is generally characterised by west and northwesterly directed structures thinning the nappe stack. The ductile to brittle extensional structures were superimposed on the tectonostratigraphy established during the Scandian phase (Fig. 2), comprising five main units (Roberts and Gee, 1985):

(1) The Autochthon-Parautochthon consist of the Fennoscandian Shield basement and the sedimentary cover of Neoproterozoic and early Palaeozoic age.

(2) The Lower Allochthon consists mainly of lowgrade sedimentary sequences of Neoproterozoic to early Palaeozoic age and some Fennoscandian Shield basement rocks are involved in the thrust sheets.

(3) The Middle Allochthon is dominated by large crystalline nappe complexes and thick psammitic sequences, locally overlain by Vendian to lower Palaeozoic metasediments.

(4) The Upper Allochthon contains mainly ophiolites and island-arc complexes and some parts which are believed to have constituted the transitional continental-oceanic crust segments of the rifted margin of Baltica.

(5) The Uppermost Allochthon is present only in northern Norway and will not be discussed further here.

Since Bjørlykke's and Hossack's suggestions (Bjørlykke, 1983; Hossack, 1984) that large-scale listric normal faults controlled formation of the Devonian basins in western Norway, considerable attention has been paid to the late- to post-orogenic extensional modification of the orogen in Scandinavia. Structures formed at various upper to lower crustal levels related to the extensional collapse have been identified in several on-shore cross-sectional traverses along-strike of the orogen (e.g., Norton, 1986; Séranne and Séguret, 1987; Andersen and Jamtveit, 1990; Fossen, 1992; Rykkelid and Andresen, 1994). The late- to post-orogenic extension in southern Norway resulted in penetrative reworking and decompression of Caledonian high-pressure metamorphic rocks, formation of large extensional detachments and the Devonian supra-detachment basins (Andersen et al., 1994; Osmundsen, 1996; Osmundsen et al., 1998). Similarly, exhumed Caledonian high-pressure rocks (Gilotti, 1994), extensional detachments and associated Devonian basin formation have recently been identified in the East Greenland Caledonides (Strachan, 1994; Hartz and Andresen, 1995; Andresen and Hartz, 1998), documenting a belt-wide late- to post-orogenic extension of the North Atlantic Caledonides. This paper attempts a review of the geometry, regional distribution and relative age of the extensional structures across the south Norwegian Caledonides.

\section{Extensional domains and structures in south Norway}

Papers presenting original data on the extensional tectonics in the Scandinavian Caledonides have focused mostly on characterising structural geometries in restricted areas and/or structural levels, or they have attempted to present large-scale conceptual tectonic models. Comprehensive documentation of the post-orogenic extension in southern Norway has so far only been published from the BergenHardanger (Fossen, 1992) and the Sogn-Nordfjord regions (Chauvet and Séranne, 1989; Dewey et al., 1993; Andersen et al., 1994; Osmundsen, 1996). The extensional structures in the eastern part of the section (Fig. 3) are less well studied. The interpretation from eastern Norway relies on reconnaissance observations by the present author, but mostly on published maps (Sigmond et al., 1984; Nilsen and Wolf, 1989), short papers and abstracts 


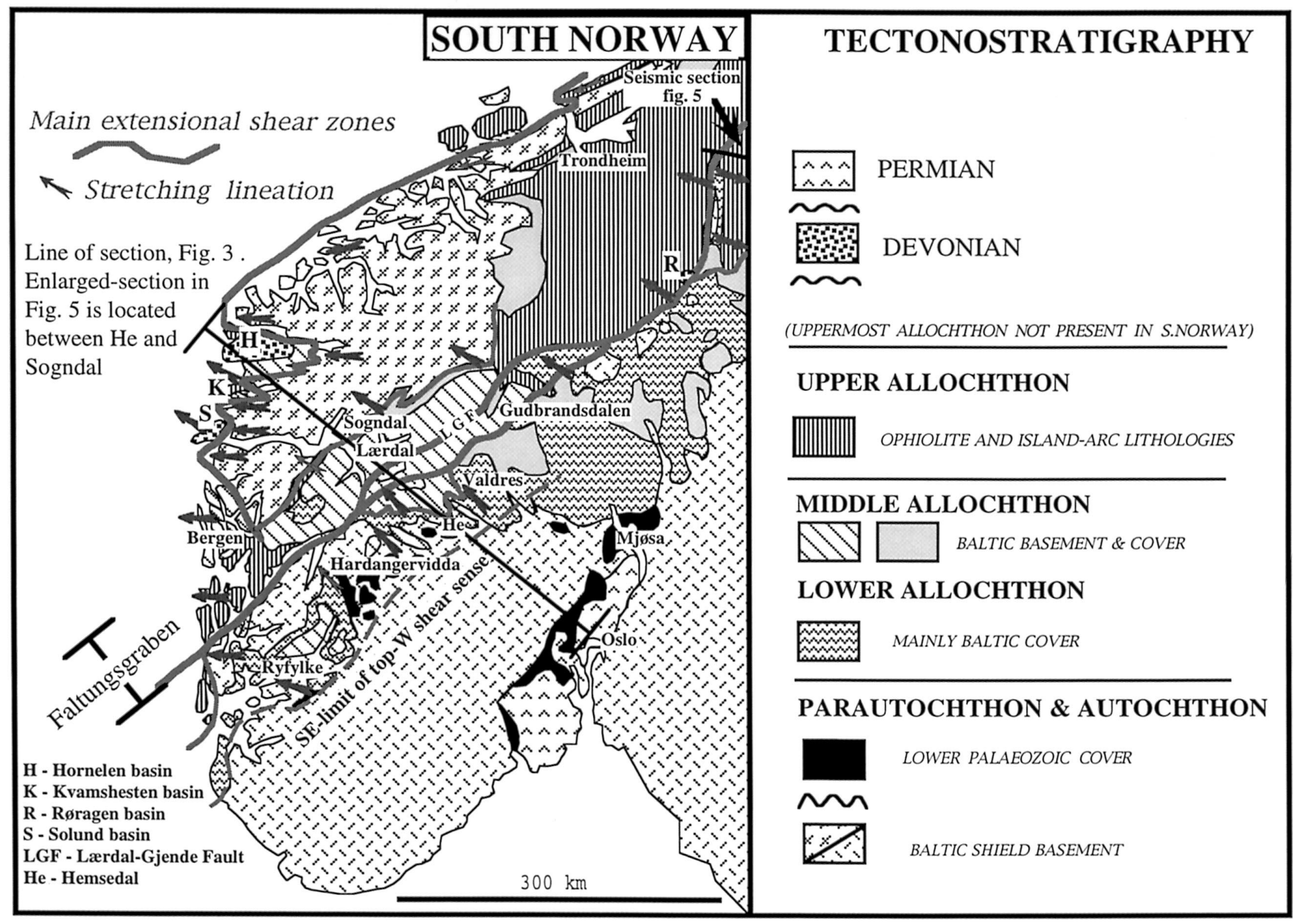

Fig. 2. Simplified map of the Caledonian tectono-stratigraphy in southern Norway. The main extensional shear zones, extension direction (lineation) and faults are shown schematically. Notice locations of profiles, Figs. 3-5. 
from the Trondheim-Östersund transect (Sjöström and Bergman, 1989, 1994; Sjöström et al., 1991) and observations adjacent to the Røragen Devonian basin (Norton, 1987; Gee et al., 1994).

The first identification of large-scale late/postCaledonian structures affecting the nappe stack of southern Norway was by Goldschmidt (1912) who identified a major NE-SW-trending synformal depression in central south Norway (Figs. 2 and 3) which he called the 'Faltungsgraben'. This structure has later been referred to as the LærdalGjende/Hardangerfjord Fault Zone (Andersen et al., 1991) or the Hardangerfjord Shear Zone (Fossen, 1992). In the following Goldschmidt's original term, Faltungsgraben, is retained because the lineament is characterised by both folding and faulting. As will become apparent from the descriptions below, the Faltungsgraben is a relatively late structure in the post-Caledonian structural modification. East of the Faltungsgraben, the Caledonian structure is characterised by relatively thin, dominantly sub-horizontal basement/cover nappes. On the eastern flank of the Faltungsgraben, Fennoscandian basement and cover as well as the nappes bend down into the NW-facing synformal depression along which structurally higher nappe units can be traced from the Hardanger-Ryfylke area in the south to the Trondheim area in the north (Fig. 2). The western flank of the Faltungsgraben is defined by the east-dipping contact zone between the Caledonian nappes and the structurally underlying Western Gneiss Region (Fig. 3).

\subsection{Extensional structures east of the Faltungsgraben}

The easternmost parts of the Caledonides in southern Norway are the foreland fold and thrust belt preserved within the upper Palaeozoic Oslo Graben (Bockelie and Nystuen, 1985; Morley, 1986a) and in the lower allochthon of the Valdres-Gudbrandsdalen (Hossack et al., 1985) and Hardangervidda areas (Andresen, 1982). The foreland is structurally characterised by imbricate fans (Oslo area) and duplexes (Valdres) developed above a sole thrust in the Cambrian to Ordovician alum-shales. The sole trust probably terminates as a blind thrust, largely masked by the Permian batholiths, in the southern parts of the Oslo Graben (Bockelie and Nystuen, 1985; Morley, 1986a). Morley (1986b) calculated some $135 \mathrm{~km}$ of accumulated shortening from the thrust front to the Mjøsa area. The youngest rocks affected by the Caledonian SE-directed thrusting in the foreland are Late Silurian (Pridoli) fluvial sandstones. According to a recent calibration of the time scale by Tucker and McKerrow (1995) the base of the Devonian is at $417 \mathrm{Ma}$. Hence the post-depositional thrusting of Late Silurian sediments in the foreland was most likely contemporaneous with the initial extensionrelated decompression of high-pressure rocks in the hinterland and therefore relevant for the late orogenic extension of the orogen (Andersen et al., 1991; Andersen, 1993). With the exception of minor pop-up structures and associated SE-dipping reverse faults there is, however, no published evidence of major top-west shearing or extensional reactivation along the decollement surface in the alum-shale sequence in the Oslo region. If present at all, obvious Basin and Range type 'breakaway zones' (Wernicke, 1992) for top-to-the-west extension has not been identified in the Scandinavian Caledonides (Figs. 2 and 3).

In the northern part of SE Norway, the Trondheim region and along the Swedish-Norwegian border, several authors have shown that the thrust-related basal decollement ramps up from deeper structures involving the Fennoscandian basement (e.g., Gee et al., 1985). An interpretation, based on semi-quantitative cross-sectional balancing (Morley, 1986b) and on seismic reflection profiles (Hurich and Kristoffersen, 1988; Hurich et al., 1989; Palm et al., 1991), indicate that the basement windows and culminations east of Faltungsgraben (Fig. 2) are allochthonous and entirely related to thrusting.

Work by Sjöström and Bergman (1989, 1994), however, demonstrates that the basement windows are exposed not merely as a result of contractional antiformal stacking (Hurich and Kristoffersen, 1988; Gee et al., 1994), but also as a result of inhomogeneous vertical shortening and horizontal extension of the nappe stack. The earliest structures thinning the nappe complexes in the structural level along the lower and middle allochthon boundary are described by Sjöström and Bergman (1994) from the Trondheim-Östersund transect. These authors state that the nappes where thinned initially by non-coaxial flow, related to east-dipping, top-to-the-southeast 


\section{SCHEMATIC CRUSTAL SECTION FROM THE OSLO AREA TO THE COAST WEST OF FLORØ}

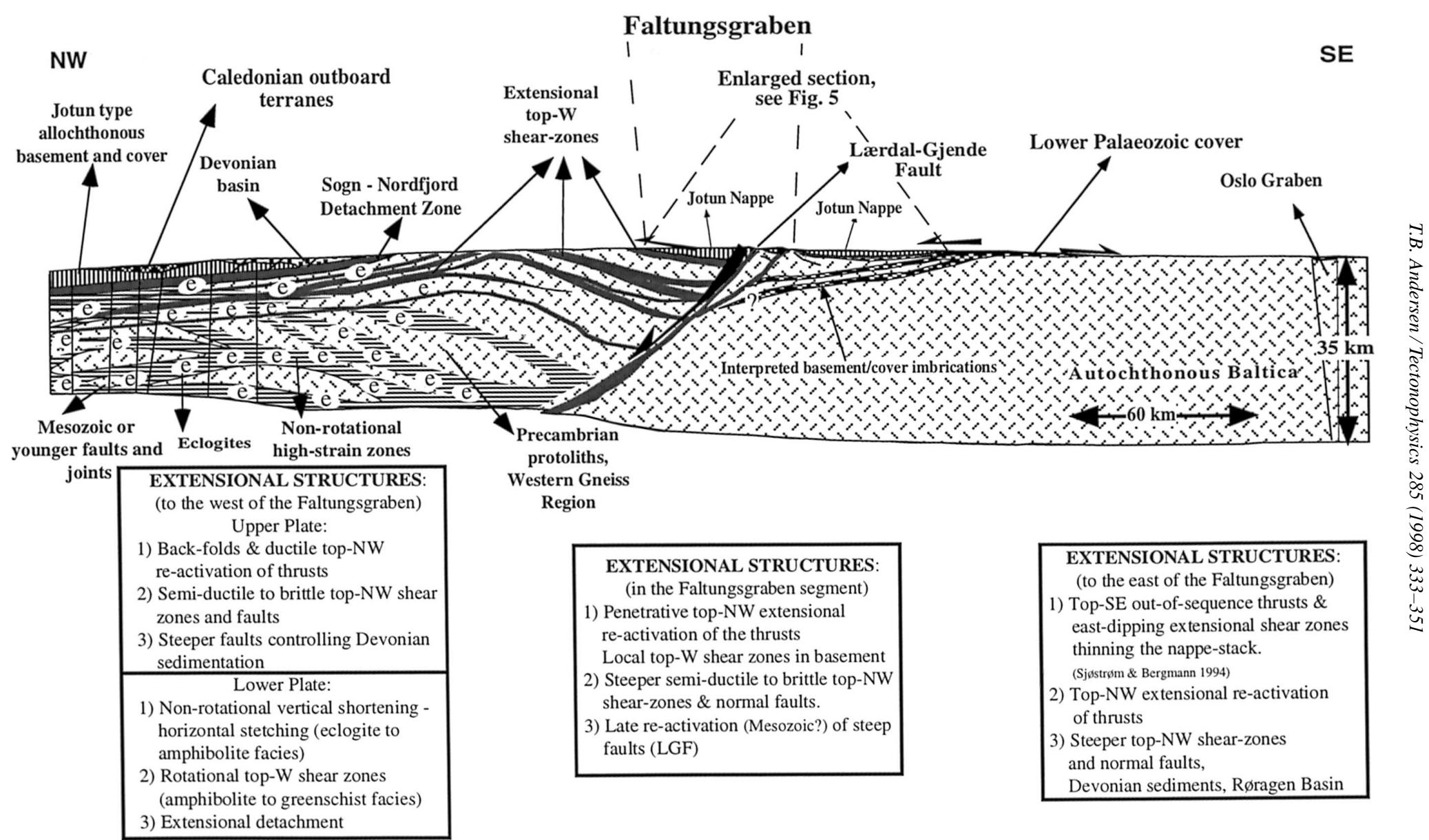

Fig. 3. Southeast-northwest profile across south Norway. The profile has been constructed from available geological maps, geophysical profiles and recent field observations. The text boxes give summaries of the extensional structures to the east, west and within the Faltungsgraben segment. Notice horizontal/vertical scale $\sim 1 / 2$. See text for discussion. 


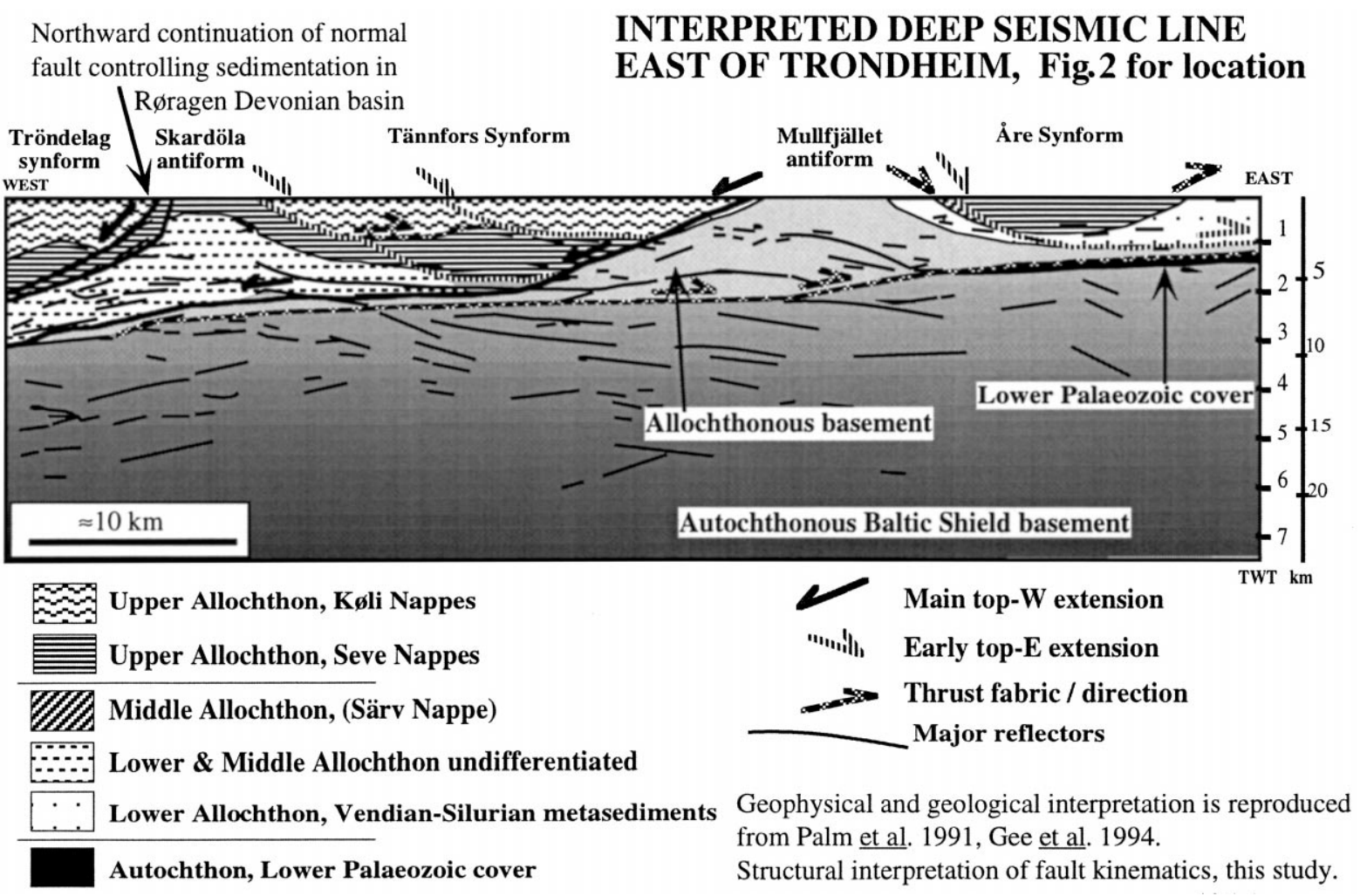

Fig. 4. Line drawing interpretation of deep-seismic reflection profile in the Swedish-Norwegian border zone east of Trondheim (see Fig. 2). The profile is reproduced from Hurich et al. (1989) and Palm et al. (1991). Interpretation of the tectono-stratigraphic units is after Palm et al. (1991) and Gee et al. (1994). The kinematic interpretation of the faults (shown by arrows) is drawn by the present author and is based on interpretations by Sjöström et al. (1991) and the structural geometry.

extensional shear zones on the southeast flanks of the basement culminations (Fig. 4). Displacement on these shear zones produced large-scale, extensionrelated synforms with higher tectonic units (Middle and Upper Allochthon) preserved in their hanging walls (Fig. 4). The east-dipping shear zones affected composite nappe units, thus demonstrating their younger relative age with respect to the true contractional structures (Sjöström and Bergman, 1994). Sjöström and Bergman (1994) concluded that ductile, out of sequence top-east shear zones near and east of the Swedish-Norwegian border in Trøndelag (see Fig. 4) were related to gravitational thinning of the nappe pile, and hence substantiate earlier suggestions (Andersen et al., 1991; Andersen, 1993; Dewey et al., 1993) that thrusting of the Lower Allochthon and development of the foreland fold and thrust belt may have been related to gravitational spreading of the orogenic belt.
Sjöström and Bergman $(1989,1994)$ have further shown that the top-east-directed extension was succeeded by large-scale, top-to-the-west, west-dipping normal faults and shear zones comparable to the Røragen Detachment (Norton, 1987). The kinematics of these faults and shear zones are documented by fabric studies (Norton, 1987; Sjöström and Bergman, 1989, 1994; Sjöström et al., 1991), and the extensional geometries are obvious on the seismic profile (Fig. 4).

Fig. 4 reproduced here is based on the published seismic reflection profile (Hurich et al., 1989; Palm et al., 1991), with geological interpretation from the same authors, and clearly indicates the extensional geometries. If the interpretation is correct, it is difficult to envisage how the sole thrust may have been active as a top-to-the-east contractional structure along its entire E-W length at the same time as the upper units where thinned by top-to-the-west extensional shear zones and faults as suggested by 
Gee (1988) and Gee et al. (1994). The surface expression of the normal faults eventually controlled formation and sedimentation in the Devonian Røragen basin (Fig. 2). Several NE-SW-trending shear and fault zones previously interpreted as thrusts have been mapped northeast of the Jotun Nappe (Sigmond et al., 1984; Nilsen and Wolf, 1989). These faults have not, to the present author's knowledge, been studied recently and no fabric analyses are presently available. The map pattern (Nilsen and Wolf, 1989) showing juxtaposition of lower structural units with higher structural units in foot and hanging walls, respectively, indicate that these structures are normal faults. It is suggested that they form part of a system co-genetic with the Lærdal-Gjende Fault (see below), and hence represent a late expression of the extensional collapse east of the Faltungsgraben in southern Norway.

Structures related to crustal extension east of the Faltungsgraben lineament include the following.

(1) Foreland-dipping shear zones recording topto-the-SE-directed displacement (Fig. 4). These structures thinned the nappe stack at greenschistfacies conditions, and are probably contemporaneous with decollement thrusting in the foreland.

(2) Reversal in polarity of deformation, with major top-to-the-NW movement along most of the previous thrust contacts (Figs. 3 and 5). A well defined breakaway zone for the top-W deformation has not been identified, but if present it is located southeast of the leading edge of the major crystalline nappes of the Hardanger-Ryfylke and Jotun Nappe Complexes (Fig. 2).

(3) Hinterland-dipping, semi-ductile to brittle shear and fault zones with large (several km) displacements. Some of these structures are responsible for the exposed basement windows/culminations by footwall uplift. The surface expression of these faults controlled formation and deposition in Devonian Røragen basin (Fig. 2).

As mentioned above, the Caledonian structure to the east of the Faltungsgraben in south-central Norway (Hardangervidda to Valdres) is characterised by relatively thin nappes belonging to the Lower and Middle Allochthon, overlying a thin autochthonous to para-autochthonous sedimentary cover and the Fennoscandian basement (Andresen and Færseth, 1982; Bryhni and Sturt, 1985; Milnes and Koestler,
1985). Kinematic indicators indicative of back-thrusting on the main tectonic contacts of the basement and cover nappes show that top-west reactivation occurred at greenschist-facies conditions (Milnes and Koestler, 1985). Recent observations by the present author and co-workers (Gathe and Andersen, 1996) show that the fabrics related to inferred (Milnes and Koestler, 1985) SE-directed thrusting is obliterated along the base of the Jotun Nappe in the Hemsedal area (Figs. 2 and 5). The structure and texture of the rocks in the basal shear zone of the Jotun Nappe are characterised by kinematic indicators and stretching lineations indicative of intense WNW-directed non-coaxial flow at greenschist-facies conditions. The entire structural thickness of the micaceous metagreywackes and phyllites of the cover on Hardangervidda as far east as exposures are available on the Haukeliseter transect, is dominated by NW-vergent folds and associated foreland-dipping crenulation cleavage around NESW-trending fold and crenulation axes (Andresen, 1982; Haremo, 1987). Similar observations have been made in the Valdres area, although the contractional duplexes are preserved in the SE part of the Valdres section (Milnes and Koestler, 1985).

A model for the back folds and the associated crenulation cleavage was suggested by Osmundsen (1990) based on studies of the upper plate in Sunnfjord. Top-to-the-west reactivation of the main thrust contacts resulted in an inverted strain field from bulk vertical stretching/horizontal shortening to vertical shortening/horizontal stretching. The extensional deformation was partitioned along the plastic instabilities defined by major thrust zones and low shear strength tectono-stratigraphic units. In these shear zones previous hinterland-dipping planes of flattening (main foliation) related to thrusting were positioned in the field of shortening and hence folded during initial top-west rotational deformation (Osmundsen and Andersen, 1994). Fossen (1992) used a similar model to explain the west- and northwestvergent folds and referred to the initial ductile top-W reactivation as Mode I extension.

\subsection{Extensional structures in, and along the Faltungsgraben lineament}

The Faltungsgraben is a complex large-scale synformal structure formed by NW-vergent folding as 


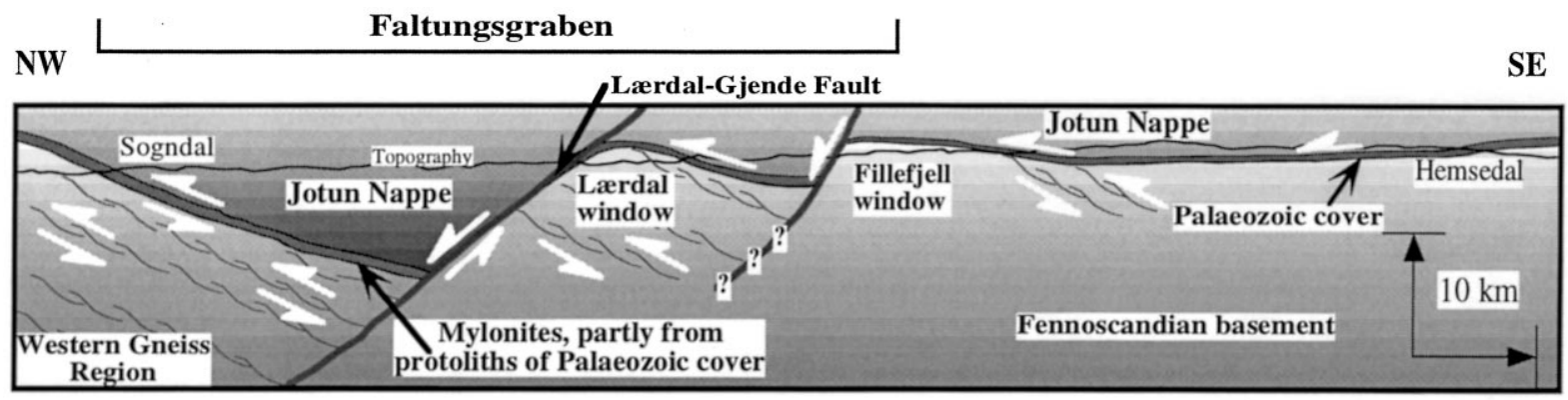

Fig. 5. Geological profile across the Faltungsgraben lineament in south-central Norway (for location see Figs. 2 and 3). The top-west, reactivation of the thrusts obliterated most of the thrust fabrics and the thickness of the Jotun Nappe was strongly modified by the extension. Notice the footwall uplift which exposes the Fillefjell and Lærdal basement windows. Notice also that ductile, top-west shear zones are present and become increasingly common towards the west in the basement and basement windows. Basement shear zones that can be related to Caledonian shortening have not been observed in this section.

well as later semi-ductile to brittle top-W shear zones and normal faults. Some of the faults along the Faltungsgraben lineament have probably been reactivated at a very late stage as indicated by the presence of unconsolidated fault rocks and half-graben geometries imaged on coast-parallel deep-seismic, offshore profiles (Hurich and Kristoffersen, 1988; Færseth et al., 1995). As described above the initial vertical shortening of the nappe stack recognised in the Swedish-Norwegian border area occurred by a top-to-the-SE, out of sequence (with respect to thrust stacking) shear zones, thinning the nappes by gravitational movements in a direction synthetic with the thrusting. Similar top-to-the-SE foreland-dipping shear zones have, however, not been identified in central SE Norway.

The SE-directed movements where succeeded by the reversal in polarity of deformation, and the main tectonic contacts were reactivated as extensional topwest shear zones (Fig. 5). As pointed out above, the fabrics related to the reversal in polarity of deformation are very common. These structures have been described in detail by Fossen (1992) across the Faltungsgraben lineament from its eastern and western limb in the Hardanger-Bergen area. Recent observations along the transect across from Hemsedal to Sogndal in central-south Norway by the present author confirms Fossen's structural observations (Fossen, 1992) of NW-directed movements on all the major tectonic contacts. The SE-dipping, western flank of the Faltungsgraben, where the nappes make contact with the rocks of the Western Gneiss Region, has been studied in two sections near Sogndal
(Fig. 2). Both sections are characterised by several hundred metres thick packages of mylonites in which top-NW to WNW kinematic indicators dominate the fabric. Near Sogndal (Fig. 2), the quality of the exposures along the new road sections on the SogndalFjærland highway, allows good relative dating of the various structural elements and kinematic indicators. Systematic observations show that the structural history is complicated; locally remnants of top-tothe-SE probably related to the thrusting of the Jotun Nappe have been preserved. The mylonites are, however, dominated by fabrics formed by top-to-the-NW non-coaxial deformation. In addition, a set of late top-to-the-SE kinematic indicators, post-dating the dominant top-NW shear fabric, has been observed. The late top-to-the-E structures are mostly represented by spaced SE-directed normal-slip crenulations and shear bands, and occur in narrow zones $(<10 \mathrm{~m})$, confined to phyllonites and talc-schists. It is suggested that the late top-E fabric records gravitational sliding down-dip into the central trough of the Faltungsgraben on horizons of low shear strength.

Within the core of the Faltungsgraben, the dominant late extensional structures are NE-SW-trending semi-ductile to brittle normal faults (Mode II extension by Fossen, 1992). These post-date the extensional top-W reactivation of the thrusts, and are clearly younger than some newly discovered ductile top-NW shear zones that occur within the basement culmination in the footwall of these faults (Gathe and Andersen, 1996). The best example of the faults is the Lærdal-Gjende Fault, which is represented by a thick zone (up to $200 \mathrm{~m}$ Milnes 
and Koestler, 1985) of cataclastic deformation affecting earlier extensional mylonites in its footwall and Jotun Nappe orthogneisses in its hanging wall (Fig. 5). At Lærdal, the footwall comprises an approximately 200-m-thick zone of top-NW mylonites, phyllonites and ultramylonites, parts of which have protoliths in the Caledonian cover beneath the Jotun Nappe. Late movements on the Lærdal-Gjende Fault are indicated by unconsolidated breccias and gauges along its fault plane. The breccias and fault gauge are presently undated. Attempts to date the breccias by palaeomagnetic method and by low-temperature thermo-chronological methods are in progress.

The Lærdal-Gjende Fault is clearly an important structure in controlling the change in the interpreted thickness of the Jotun Nappe from a few hundred metres in its footwall to several kilometres in its hanging wall (Fig. 5) also indicated by gravity modelling by Smithson et al. (1974). The southwestward continuation of the Faltungsgraben has been described in detail by Fossen (1992). Its offshore continuation has been imaged on the coastparallel 'Mobil Search' deep-seismic profiles, where the late normal movements are demonstrated by the occurrences of late Palaeozoic/early Mesozoic (?) half-grabens in its hanging wall (Hurich and Kristoffersen, 1988; Færseth et al., 1995).

\subsection{Extensional structures in western Norway}

The late- to post-orogenic extension in western Norway has been studied and described in a number of theses and publications since the late 1980s. Traditionally, the exhumation of high-pressure rocks in western Norway was attributed to erosional processes combined with thrust tectonics (Cuthbert et al., 1983). One of the most remarkable features of the geology in western Norway is the juxtaposition of late Caledonian eclogites in the footwall (age $\sim 400$ $420 \mathrm{Ma}$, pressure 15 to $>30 \mathrm{kbar}$ ), with Lower and Middle Devonian sedimentary rocks $(\sim 390 \mathrm{Ma})$ in the hanging wall across the Nordfjord-Sogn Detachment. A major difference in the extensional fabrics between western, central and eastern S Norway is the degree with which the Fennoscandian basement is involved in the extensional deformation. To the east of the Faltungsgraben the basement has, as far as one knows, not been significantly affected by ex- tensional deformation. On the eastern flank of the Faltungsgraben the basement has been locally affected, mostly adjacent to the basal thrust zone of the nappes (Fossen, 1992). Along the core of the Faltungsgraben, basement rocks from deeper levels exposed in the footwall of late normal faults are mylonitised in top-W shear zones of up to $150-200$ $\mathrm{m}$ structural thickness (see also Fig. 5). The rocks of the Western Gneiss Region along the western flank of the Faltungsgraben are strongly affected by the late Caledonian extensional deformation in a zone down to a few hundred metres below the basementcover contact. At deeper structural levels the extensional fabrics become increasingly abundant and intense as one approaches the detachments (Milnes et al., 1988). In western Norway, however, deformation related to the extensional decompression of the Fennoscandian basement lithologies within the Western Gneiss Region is pervasive (e.g., Andersen and Jamtveit, 1990; Dewey et al., 1993; Andersen et al., 1994).

The significance of the Nordfjord-Sogn Detachment was initially recognised by Norton (1986, 1987). The contrast in late Caledonian regional metamorphism between the upper (low grade) and lower plate (eclogite facies) of the detachment requires omission of a minimum of 35 to $40 \mathrm{~km}$ crustal section in the Sunnfjord area (Andersen and Jamtveit, 1990) and more than $50 \mathrm{~km}$ in the Nordfjord area from the Late Silurian ( $\sim 20$ to $425 \mathrm{Ma})$ to the Lower Devonian ( 390 to $400 \mathrm{Ma})$. The period of time (20 to $35 \mathrm{Ma}$ ) during which this dramatic reduction in crustal thickness took place is estimated on the basis of previously published geochronological data from the Western Gneiss Region (see compilation by Kullerud et al., 1986; Wilks and Cuthbert, 1994) and by ${ }^{40} \mathrm{Ar} /{ }^{39} \mathrm{Ar}$ mineral cooling ages (Berry et al., 1993, 1995) from the lower and upper plate of the detachment (Fig. 6).

Below, a summary of the structures related to the decompression and sub-horizontal extension of the lower as well as the upper plate lithologies is described. For details and documentation refer to the original papers (cf. Norton, 1986; Séranne and Séguret, 1987; Chauvet and Séranne, 1989), and papers by the present author and co-workers (see references). 


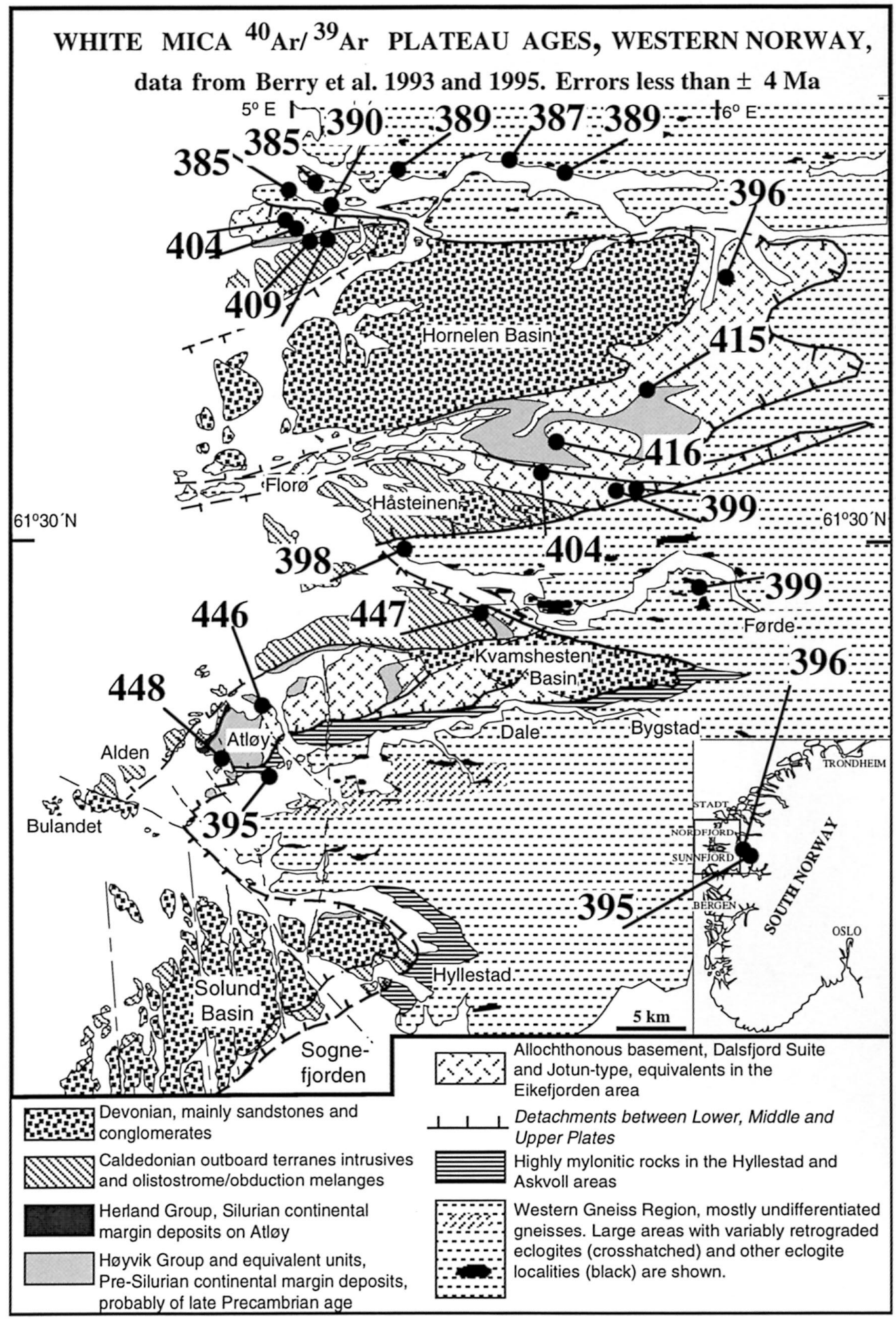

Fig. 6. Geological map of western Norway (after Andersen et al., 1994). The white mica, conventional ${ }^{40} \mathrm{Ar} /{ }^{39} \mathrm{Ar}$ cooling ages are from Berry et al. $(1993,1995)$. All ages presented are well defined plateau ages. Comprehensive descriptions and interpretations of the Ar-geochronology will be presented elsewhere (Andersen et al., 1998) and work in progress). 


\subsubsection{Extensional decompression of the lower plate}

A model suggesting that the initial extensional decompression of the hinterland eclogites in the Western Gneiss Region occurred contemporaneously with contractional tectonics in the foreland was put forward by Andersen et al. (1991). The principal structures and fabrics in the exhumed deep-crustal rocks that have been related to the decompression of the lower plate rocks are: (1) by coaxial vertical shortening/horizontal stretching at eclogite- to amphibolite-facies conditions; and (2) by non-coaxial deformation related to extensional detachments and shear zones at amphibolite- to greenschist-facies conditions.

Coaxial decompression fabrics in the exhumed deepcrust of the lower plate. Because of the complete sections from the lower to the upper part of the synorogenic crust that are available in western Norway, it has been possible to suggest models, based on field observations, of how the extensional collapse in the hinterland of the orogen may have been accommodated at various structural levels of the syn-orogenic crust. During the initial stages of the decompression (Stage 1) the lower crust was apparently shortened vertically and stretched horizontally (Andersen et al., 1994). The structures related to this event are represented by eclogite- to amphibolite-facies coaxial fabrics (Andersen et al., 1994; Engvik, 1994; Dransfield, 1994). These fabrics are present in the interior and around well preserved to variously retrograded eclogites. The coaxial fabrics apparently dominate the structure of the gneisses structurally below the detachment mylonites in the Sunnfjord and Nordfjord areas (Andersen et al., 1994; Dransfield, 1994). Detailed studies of the structures associated with the initial decompression of the eclogites suggest an overall coaxial strain regime. Associated hydro-fracturing and segregation of fluid-rich granitic leucosomes by partial melting locally altered the rheology and enhanced the deformation in the zones where they were formed/introduced. Abundant extensional quartz veins emplaced normal to the stretching and parallel to shortening directions at various stages of the deformation, indicate that the orientation of the principal strain axes remained constant during Stage 1 decompression (Andersen et al., 1994). Temperature-pressure estimates from the Sunnfjord area (Krogh, 1980; Andersen and Jamtveit, 1990; Engvik, 1994) from eclogitefacies $\left(T \approx 550-600^{\circ} \mathrm{C}, P_{\min } \approx 16 \mathrm{kbar}\right.$, age $\sim 415$ Ma) to amphibolite-facies conditions $\left(T \approx 600^{\circ} \mathrm{C}\right.$, $P \approx 10 \mathrm{kbar}$, age $\sim 400-405 \mathrm{Ma})$ during Stage 1 corresponds to a near-isothermal removal of overburden of at least $20 \mathrm{~km}$, corresponding to a denudation rate of $1.5 \mathrm{~mm} /$ year or more.

Rotational deformation related to the detachments. The second major event (Stage 2) related to the decompression of the high-pressure rocks in the lower plate rocks in the Western Gneiss Region is represented by formation of amphibolite- to greenschist-facies non-coaxial mylonites of the extensional detachments. The fabrics of the detachment mylonites formed by rotational deformation with consistent top-to-the-west displacement will not be described in detail here. The top-W sense of shear is documented by a variety of kinematic indicators which have been described in several theses and papers previously (cf. Norton, 1986, 1987; Chauvet and Séranne, 1989; Swensson and Andersen, 1991; Hveding, 1992; Wilks and Cuthbert, 1994).

Although impossible to measure accurately, Hveding (1992) estimated shear strains of more than 20 (detailed fabric analyses) in the Nordfjord-Sogn Detachment mylonites in Sunnfjord. The semi-ductile late shear bands which are ubiquitously present in the detachment zone where not included in Hveding's strain analyses (Hveding, 1992). This implies that the normal displacement related to the mylonitisation on the $2.5-\mathrm{km}$-thick detachment zone probably was greatly in excess of $40 \mathrm{~km}$. Furthermore, the brittle movements represented by cataclastites and breccias, and more than $10 \mathrm{~km}$ of normal displacement after deposition of the Kvamshesten Devonian basin must be added to the total displacement (Osmundsen, 1996; Osmundsen et al., 1998). Hence, the minimum normal displacement of the NordfjordSogn Detachment in the Sunnfjord area is considerably more than $50 \mathrm{~km}$. Together with the coaxial vertical shortening of more than $50 \%$ (Dewey et al., 1993) related to the fabrics of Stage 1, more than 50 $\mathrm{km}$ of normal displacement on the Nordfjord-Sogn Detachment zone dipping at a moderate $20-30^{\circ}$ during the initial movements, is sufficient to explain exhumation of the high-pressure lower crustal rocks 
by extensional tectonics and footwall uplift even without major erosional denudation. The present dip of the detachment is approximately $12^{\circ}$ to $15^{\circ}$ (Osmundsen, 1996) measured along the axis of the late E-W-trending folds that post-date the Devonian basins and their substrate (see below).

A regional study of ${ }^{40} \mathrm{Ar} /{ }^{39} \mathrm{Ar}$ mineral cooling ages from muscovite in the Western Gneiss Region of the Sunnfjord and Nordfjord areas apparently gives consistent results on the local and regional scale and demonstrates significant diachronous cooling in the lower plate (Fig. 6). The lower-temperature $\left(\sim 600^{\circ} \mathrm{C}\right)$ eclogite-bearing rocks in the SognSunnfjord region cooled below Ar-retention in muscovite at $\sim 398 \pm 3 \mathrm{Ma}$, whereas the high-temperature $\left(\sim 700^{\circ} \mathrm{C}\right)$ eclogite terrain in Nordfjord cooled at $\sim 389 \pm 3 \mathrm{Ma}$ (Berry et al., 1993, 1995). It is suggested that the diachronous cooling with younger muscovite ages in Nordfjord compared to those in Sunnfjord, is a function of the higher pressures and consequently original deeper burial, of the rocks in Nordfjord.

\subsubsection{Extensional structures in the upper plate}

The most important result of the extensional deformation in the upper plate of the NordfjordSogn Detachment is the formation of the Devonian supra-detachment sedimentary basins (see below). In addition a number of post-Caledonian extensional and contractional structures have been identified and systematically studied. These include: (1) top-westdirected major and small-scale ductile shear zones; (2) west-vergent folds; (3) semi-ductile to brittle normal and transtensional faults; (4) large-scale upright to weakly overturned east-west-trending folds affecting the entire tectono-stratigraphy in the SognSunnfjord region; and finally (5) high-angle faults and fractures that off-set all previous structures, including the Nordfjord-Sogn Detachment. The geology of the hanging wall of the Nordfjord-Sogn Detachment has been described in detail by Osmundsen (1996) and Osmundsen and Andersen (1994).

${ }^{40} \mathrm{Ar} /{ }^{39} \mathrm{Ar}$ mineral ages of muscovite from rocks in the upper plate of the Nordfjord-Sogn Detachment (Fig. 6) demonstrate polyphase cooling and crystallisation events. The pre-Silurian rocks were affected by an early Caledonian, pre-Scandian event (muscovite ages 445-450 Ma in the Atløy area;
Fig. 6) as well as Scandian and post-Scandian recrystallisation/cooling of $410 \mathrm{Ma}$ to $420 \mathrm{Ma}$ (Fig. 6).

The lack of equilibration and resetting of the $\mathrm{Ar}-$ system in muscovite is a result of variable but generally low-grade regional metamorphism in the upper plate during the Scandian event (Andersen et al., 1998). Consequently, rocks that were little affected by Scandian deformation have retained the pre-Scandian cooling ages, whereas deformation and new growth of muscovite in zones affected by Scandian and post-Scandian give younger ages. The ${ }^{40} \mathrm{Ar} /{ }^{39} \mathrm{Ar}$ muscovite ages from Berry et al. (1993, 1995) are in accordance with previously interpretations (Andersen et al., 1990; Osmundsen and Andersen, 1994) that demonstrated the polyphase nature of both contractional and extensional deformation in the upper plate and suggested that a middle plate was present between the Hornelen and Nordfjord-Sogn Detachments (Andersen and Jamtveit, 1990).

Ductile to brittle extensional structure in the substrate of the Devonian basins. The shear zones (1), west-vergent folds (2) and faults (3) apparently represent a continuous ductile to semi-brittle mode of deformation related to a bulk vertical shortening and E-W extension of the thickened crust. The origin of the top-W reactivated shear zones and the mechanisms for the formation of the west-vergent folds have been discussed above. These correspond to the Mode I extension of Fossen (1992). The later brittle normal and transtensional faults (3) transect composite tectonic units and record progressive extensional deformation during exhumation of the Caledonian nappes of the upper plate, prior to and during deposition of the Lower (Solund) to Middle Devonian (Kvamshesten and Hornelen) basins (Osmundsen, 1996).

\subsubsection{Devonian supra-detachment basins}

The Devonian basins exposed in western Norway (Fig. 6) are supra-detachment basins situated in the hanging wall of the regional Nordfjord-Sogn Detachment. The basins display extraordinary stratigraphic thicknesses of mainly alluvial and fluvial sediments. Early models on basin formation (cf. Bryhni, 1964; Nilsen, 1968; Steel and Gloppen, 1980) were focused on the basin fill. After the recognition of the large-scale extensional detachment, models 
for formation of the basins have principally emphasised the importance of the detachment as the major control on Devonian sedimentation (Hossack, 1984; Norton, 1986; Séranne and Séguret, 1987; Séguret et al., 1989). Clasts from the lower plate of the detachment have, however, not been identified within any of the basins (Cuthbert, 1991; Osmundsen, 1996; Osmundsen et al., 1998). Thus, the rocks of the lower plate of the detachment were probably not exhumed at the time of basin formation.

The Kvamshesten basin and its depositional substrate (Osmundsen and Andersen, 1994; Osmundsen et al., 1998) highlight the importance of intra-upper plate extensional and transcurrent faults prior to, as well as synchronous with Devonian sedimentation. The facies distribution within the basin is highly asymmetric, the locus of maximum subsidence has shifted with time from the northern to the southeastern margin, and syn-sedimentary faults controlled the migration of facies belts with time. The present detachment fault constituting the boundary between the upper and lower plate did not control sedimentation in the basin and represents post-depositional reactivation of the main detachment (Torsvik et al., 1992; Osmundsen, 1996). Detailed studies in the Kvamshesten basin (Osmundsen et al., 1998) show that the sedimentation was controlled by upper plate normal faults which were rooted in or cut by the detachment. Similar faults have been mapped along the basal unconformity of the Hornelen basin (Hartz, 1998). Andersen and Jamtveit (1990) suggested the presence of a detachment above the main NordfjordSogn Detachment, separating the middle and upper crustal rocks, and controlling formation of the Hornelen basin. This interpretation has been substantiated by Wilks and Cuthbert (1994), and is also supported by older muscovite cooling ages in the middle plate between the Hornelen and Håsteinen basin, which previously has been considered to form part of the lower plate. The geometry and kinematics of normal and transtensional faults above the Nordfjord-Sogn Detachment are highly complex as described in some detail by Osmundsen (1996) and, consequently, the details of the fault-controlled sedimentation in the Devonian basins is similarly complex.
East-west-trending folds. The east-west-oriented dominantly upright folds in western Norway affect the entire crustal section including the decompressed high-pressure rocks of the Western Gneiss Region and the youngest Devonian sediments in the basins. It is, however, important to note that folds in both the upper and lower plates are truncated by the brittle reactivated detachment faults along the Kvamshesten and Hornelen basins. The folds record a phase of $\mathrm{N}-\mathrm{S}$-directed shortening. Various models have been suggested to explain the folding, but the exact cause of this folding is still uncertain. Hossack (1984) and Norton (1987) indicated that the syn- and antiforms defined by the detachment were related to primary corrugations of the detachment surface commonly observed in the Basin and Range Province. The folds in the upper plate were accommodation structures and thus syn-depositional with respect to the sedimentation in the Devonian basins. Chauvet and Séranne (1994) considered the folding to be syndepositional and a result of external forces related to a re-arrangement of the relative plate movements after the Caledonian Orogeny and Hercynian tectonics to the south. The arguments for syn-depositional folding with respect to the Devonian basins were partly based on aerial photograph interpretations (Séranne, 1988) suggesting the presence of intrabasinal unconformities in the Hornelen and Kvamshesten basins. The unconformities have not been confirmed by later detailed ground mapping (Wilks and Cuthbert, 1994; Osmundsen, 1996). Based on comprehensive mapping of the Kvamshesten basin and its depositional and tectonic substrate, Osmundsen et al. (1998) interpreted the E-W-trending folds to record a stage of essentially post-depositional N-S shortening associated with constrictional deformation during $\mathrm{E}-\mathrm{W}$ extension. The $\mathrm{N}-\mathrm{S}$ shortening of the Devonian basins is apparently younger than the basin fill, and may be of Late Devonian age as suggested previously by the palaeomagnetic data (Torsvik et al., 1987). It is possible that this deformation may be related to a large-scale re-arrangement of the plate-motion configuration and external forces as suggested by Chauvet and Séranne (1994). 


\subsubsection{Continued late Palaeozoic-early Mesozoic extension}

Dating of fault rocks along the Nordfjord-Sogn Detachment (Torsvik et al., 1992) records Permian as well as Late Jurassic brittle movements on the detachment. In addition, two sets, NW-SE (older) and N-S (younger), of high-angle normal faults and extensional fractures are present (Osmundsen, 1996). Both off-set the Nordfjord-Sogn Detachment demonstrating that the rocks on-shore western Norway experienced late, sub-horizontal eastwest-directed crustal stretching. Dolerites and rare lamprophyres (middle Permian) are locally present in the Sunnfjord area (Furnes et al., 1982; Torsvik et al., 1997) and one of these cross-cut the detachment. South of Bergen, Triassic (?) to Jurassic dolerites (K/Ar dating; Færseth et al., 1976) have been emplaced along the $\mathrm{N}-\mathrm{S}$-trending fractures system, hence a Mesozoic age is suggested for this system north of Bergen (Osmundsen and Andersen, 1994). Although the precise age of fault rocks along the Lærdal-Gjende and other normal faults along the Faltungsgraben lineament is presently unknown, it is tentatively suggested that their brittle reactivation represents the easternmost expression of the late Palaeozoic to Mesozoic extension on the S Norwegian mainland.

Work in progress on the adjacent offshore areas suggests that late Palaeozoic rifting constitutes an important event in the Horda Platform area, and that it was associated with development of half-grabens with shifting polarities (Christiansson et al., 1995). Furthermore, the magnitude of extension accommodated in the upper Palaeozoic-earliest Mesozoic far exceeds extension associated with the Late Jurassic rift phase. With exception of the Viking Graben area, the most significant phase of extension in the North Sea region is probably Devonian to late Palaeozoic in age. The magnitude of displacement accommodated by the detachment exposed onshore western Norway, strongly suggests that the offshore continuation of the detachment must have been a significant structural dislocation during Permian to early Mesozoic rifting in the northern North Sea area. Thus, the Devonian extensional fabrics were likely to form a structural template that was also important during subsequent extension.

\section{Summary and conclusions}

Because of extreme denudation, good accessibility and the quality of exposure of rocks from different crustal levels of the syn-orogenic crust, the Scandinavian Caledonides represents a unique natural laboratory to study the products of the tectonic processes associated with orogenic collision and extensional collapse of continental collision zones. The relationships between contractional and extensional deformation developed (e.g., Hodges et al., 1993) during the collision between India and Eurasia probably represents the best Cenozoic analogue to the Silurian continental collision between Baltica and Laurentia and its extensional modification.

The extensional structures in the south Norwegian Caledonides record the tectonic denudation of the Caledonian nappe pile which were assembled by polyphase lower Palaeozoic plate convergence. Because exhumed rocks in the metamorphic core complex of the Western Gneiss Region, record high- and ultra-high-pressure metamorphism (cf. Smith, 1984; Griffin, 1987; Jamtveit, 1987), it is suggested that the Caledonian Orogen developed extremely thick continental crust capable of stabilising coesite (Smith, 1984) and micro-diamonds (Dobrzhinetskaya et al., 1995). Subduction of continental crust, however, requires pervasive eclogitizaton in order to maintain a reasonable topography above the thickened crust (Richardson and England, 1979; Dewey et al., 1993).

The earliest structures recording tectonic denudation of the nappe stack in southern Scandinavia may be assigned to internal forces within the overthickened lithosphere of the orogen. The pressuretemperature estimates combined with geochronological data (Kullerud et al., 1986; Chauvet and Dallmeyer, 1992; Berry et al., 1993, 1995; Wilks and Cuthbert, 1994) indicate that decompression of the high- and ultra-high-pressure rocks in the Western Gneiss Region commenced in the Late Silurian (420 $\mathrm{Ma}$ ) and that the lower plate rocks had cooled from their maximum temperatures of $\sim 600^{\circ}$ to $750^{\circ} \mathrm{C}$ below the Ar-blocking temperature of muscovite $\left(350 \pm 50^{\circ} \mathrm{C}\right)$ at $390 \pm 10 \mathrm{Ma}$. Structural observations (Andersen and Jamtveit, 1990; Andersen et al., 1994; Osmundsen and Andersen, 1994; Dransfield, 1994) suggest that the decompression of the deep-seated rocks initially was related to non-rotational verti- 
cal shortening and horizontal stretching at depth and non-coaxial extensional shearing and normal faulting in the middle and upper parts of the thickened crust. These observations support an early model of lower crustal pure shear and upper crustal simple shear suggested by McClay et al. (1986) based on very limited field observations from western Norway and a comparison with the Basin and Range Province of the western USA. Traditional interpretations, that the eclogite-bearing rocks approached the surface by thrusting and erosion, are not supported by structural observations/fabric analyses in the Western Gneiss Region.

In the tectonically telescoped rocks of the miogeocline (Lower and Middle Allochthon) of the eastern part of the orogen, initial vertical thinning and unroofing apparently occurred by top-to-the-E, out-of-sequence extensional shear zones (Sjöström et al., 1991; Sjöström and Bergman, 1994). The eastward transport on foreland-dipping shear zones were rooted on the sole thrust, suggesting that final stages of decollement thrusting in the foreland may have been related to gravitational spreading of the orogen (Andersen et al., 1991; Andersen, 1993).

The mechanism which triggered the extensional deformation in the Caledonides can only be inferred by comparison with theoretical models and comparable regions with active tectonics. By analogy with models for orogenic extensional collapse (Dewey, 1988; England and Houseman, 1988; Platt and England, 1994), it is conceivable that hinterland uplift and decompression by top-east extensional shear zones in the telescoped miogeocline, may have been a consequence of thinning of the mantle lithosphere as previously suggested (Andersen and Jamtveit, 1990; Andersen et al., 1991). This process would have increased the syn-orogenic surface slope, and it could also have reduced the dip of the sole thrust in the eastern parts of the orogen. Both geometrical adjustments, combined with reduced rate of convergence, would favour gravitational spreading of the mountain belt (England and Houseman, 1988; Platt, 1993). After initial extension possibly related to gravitational spreading, belt-wide reversal in the polarity of deformation, from top-east to top-west, occurred in the Scandinavian Caledonides with exception of the thin-skinned foreland fold and thrust belt. Contemporaneous top-to-the-east exten- sion characterised the East Greenland Caledonides (Hartz and Andresen, 1995; Andresen and Hartz, 1998). In the hinterland of the Caledonides in southern Norway, major top-to-the-west extension on the extensional detachments with heaves in the order of 50 to $100 \mathrm{~km}$, in the Lower to Middle Devonian.

The surface expression of the extensional shearing was normal and transtensional faulting (Osmundsen, 1996), controlling formation of the Devonian supradetachment basins. Previous models appealing to direct control of the sedimentation in the Old Red basins in western Norway by the main NordfjordSogn Detachment (Séguret et al., 1989) do not explain the highly asymmetric facies distribution in the basins (Osmundsen et al., 1998) and the lack of eclogites or other high-pressure rocks with provenance in the lower plate within the basins (Cuthbert, 1991; Osmundsen, 1996).

Continued Devonian and later upper Palaeozoic extension of the Caledonian Orogen in the North Atlantic region may to a large extent have been controlled by a reorganisation of the plate-motion configuration in the area, from general plate convergence to divergence or transtension. Fossen (1992) argued that a wholesale reorganisation of plate motions was necessary to explain the belt-wide reversal in deformation polarity. Chauvet and Séranne (1994) related the change in tectonic regime in western Norway to external forces related to the Hercynian plate convergence to the south. Divergent plate motions separating Baltica and Laurentia during the late Palaeozoic are, however, too small to be detected within the uncertainties of palaeomagnetic analyses (Torsvik et al., 1996). Some plate divergence seems, however, highly probably in view of the very large extension that can be inferred from the hinterland in Scandinavia, Greenland and the respective continental shelves. Late, large-scale motions sub-parallel to the strike of the orogen, such as the presently active wrench faults in the Himalaya-Tibetan region (Brunel et al., 1995; Tapponnier et al., 1995; Searle, 1995) may have been important in accommodating divergence during the later stages of the deformation in the Scandinavian Caledonides (Séranne, 1992).

The hinterland regions of the Scandinavian and Greenland Caledonides have, since the main lithospheric thickening occurred in the Late Silurian, been a region characterised by extensional tectonics. 
The extension of the Caledonides of the North Atlantic region and adjacent offshore areas may very well illustrate the long-term effect of orogenic extensional collapse as modelled by Platt and England (1994). Externally driven plate divergence and/or transtension was probably an important element in driving the extension after the Middle Devonian.

\section{Acknowledgements}

This research has been financed by grants from the Norwegian Research Council. The author would like to thank Dr. Per-Terje Osmundsen and Prof. Arild Andresen for the many stimulating discussions and corrections. I am grateful for suggestions for improvement by Dr. Laurent Jolivet and Dr. Alan Chauvet whose very thorough review improved this paper.

\section{References}

Andersen, T.B., 1993. The role of extensional tectonics in the Caledonides of south Norway: Discussion. J. Struct. Geol. 15, 1379-1380.

Andersen, T.B., Berry, H.N., Lux, D.R., Andresen, A., 1998. The tectonic significance of pre-Scandian ${ }^{40} \mathrm{Ar} /{ }^{39} \mathrm{Ar}$ phengite cooling ages the Caledonides of western Norway. J. Geol. Soc. London, in press.

Andersen, T.B., Jamtveit, B., 1990. Uplift of deep crust during orogenic extensional collapse: A model based on field studies in the Sogn-Sunnfjord region, W Norway. Tectonics 9, 10971111.

Andersen, T.B., Jamtveit, B., Dewey, J.F., Swensson, E., 1991. Subduction and eduction of continental crust; major mechanisms during continent-continent collision and orogenic extensional collapse. Terra Nova 3, 303-310.

Andersen, T.B., Osmundsen, P.-T., Jolivet, L., 1994. Deep crustal fabrics and a model for the extensional collapse of the southwest Norwegian Caledonides. J. Struct. Geol. 16, 1191-1203.

Andersen, T.B., Skjerlie, K.P., Furnes, H., 1990. The Sunnfjord Melange, evidence of Silurian ophiolite accretion in the West Norwegian Caledonides. J. Geol. Soc. London 147, 59-68.

Andresen, A., 1982. Stratigraphy and Structural History of the Lower Paleozoic Metasediments on Hardangervidda, South Norway. Ph.D. thesis. Univ. of California, 260 pp.

Andresen, A., Færseth, R., 1982. An evolutionary model for the southwest Norwegian Caledonides. Am. J. Sci. 282, 756-782.

Andresen, A., Hartz, E., 1998. A late orogenic extensional origin for the infracrustal gneiss domes of the East Greenland Caledonides $\left(72^{\circ}-74^{\circ} \mathrm{N}\right)$. Tectonophysics, this volume.

Berry, H.N., Lux, D.R., Andresen, A., Andersen, T.B., 1993. Argon 40-39 dating of rapidly uplifted high-pressure rocks during late-orogenic extension in southwest Norway. (Abstr.) Geol. Soc. Am., Annual Meeting, Boston.

Berry, H.N., Lux, D.R., Andresen, A., Andersen, T.B., 1995. Progressive exhumation during orogenic collapse as indicated by ${ }^{40} \mathrm{Ar} /{ }^{39} \mathrm{Ar}$ cooling ages from different structural levels, southwest Norway. Geolognytt 1, 20-21.

Bjørlykke, K., 1983. Subsidence and tectonics in late Precambrian and Palaeozoic sedimentary basins of southern Norway. Nor. Geol. Unders. Bull. 380, 159-172.

Bockelie, J.F., Nystuen, J.P., 1985. The southeastern part of the Scandinavian Caledonides. In: Gee, D.G., Sturt, B.A. (Eds.), The Caledonide Orogen: Scandinavia and Related Areas. J. Wiley, Chichester, pp. 69-88.

Brunel, M., Arnaud, N., Tapponnier, P., 1995. Kongur Shan normal fault: Type example of mountain building assisted by extension (Karakoram Fault, eastern Pamir). Terra Nova, Abstr. Vol. 7, 43.

Bryhni, I., 1964. Migrating basins on the Old-Red continent. Nature 202, 284-285.

Bryhni, I., Sturt, B.A., 1985. Caledonides of southwestern Norway. In: Gee, D.G., Sturt, B.A. (Eds.), The Caledonide Orogen: Scandinavia and Related Areas. J. Wiley, Chichester, pp. 89-107.

Chauvet, A., Dallmeyer, R.D., 1992. ${ }^{40} \mathrm{Ar} /{ }^{39} \mathrm{Ar}$ mineral dates related to Devonian extension in southeastern Scandinavian Caledonides. Tectonophysics, 210, 155-177.

Chauvet, A., Séranne, M., 1989. Microtectonic evidence of Devonian extensional westward shearing in southwest Norway. In: Gayer, R.A. (Ed.), The Caledonide Geology of Scandinavia. Graham and Trotman, London, pp. 245-254.

Chauvet, A., Séranne, M., 1994. Extension-parallel folding in the Scandinavian Caledonides: implications for late-orogenic processes. Tectonophysics 238, 31-54.

Christiansson, P., Odinsen, T., Berge, A.M., Faleide, J.I., Gabrielsen, R.H., 1995. Crustal structure from deep seismic data in the northern North Sea. Terra Nova, Abstr. Vol. 7, 55.

Cuthbert, S.J., 1991. Evolution of the Hornelen Basin, west Norway: new constraints from petrological studies of metamorphic clasts. In: Moton, A.C. Todd, S.P., Haughton, P.D.W. (Eds.), Developments in Sedimentary Provenance Studies. Geol. Soc. London, Spec. Publ. 57, 343-360.

Cuthbert, S.J., Harvey, M.A., Carswell, D.A., 1983. A tectonic model for the metamorphic evolution of the Basal Gneiss Complex, Western South Norway. J. Metamorph. Geol. 1, 63-90.

Dewey, J.F., 1988. Extensional collapse of orogens. Tectonics 7, $1123-1139$.

Dewey, J.F., Ryan, P.D., Andersen, T.B., 1993. Orogenic uplift and collapse, crustal thickness, fabrics and metamorphic changes: The role of eclogites. Geol. Soc. London, Spec. Publ. 76, 325-343.

Dobrzhinetskaya, L.F., Eide, E.A., Larsen, R.B., Sturt, B.A., Trønnes, R.G., Smith, D.C., Taylor, W.R., Posukova, T.V., 1995. Microdiamond in high-grade metamorphic rocks of the Western Gneiss region, Norway. Geology 23, 597-600.

Dransfield, M., 1994. Extensional Exhumation of High-Grade Rocks in Western Norway and the Zanskar Himalaya. Dr. Ph. Thesis, Univ. of Oxford. 
England, P.C., Houseman, G.A., 1988. The mechanics of the Tibetan Plateau. Philos. Trans. R. Soc. London, Ser. A 326, 301-320.

Engvik, A.K., 1994. Tektonometamorf utvikling av Vårdalsneseklogitten og omgivende bergarter, Sunnfjord, Vest-Norge. Cand. Sci. Thesis, Univ. of Oslo.

Fossen, H., 1992. The role of extensional tectonics in the Caledonides of south Norway. J. Struct. Geol. 14, 1033-1046.

Furnes, H., Mitchell, J.G., Robins, B., Ryan, P.D., Skjerlie, F.J., 1982. Petrography and geochemistry of peralkaline, ultrapotassic syenite dykes of Middle Permian age, Sunnfjord, West Norway. Nor. Geol. Tidsskr. 62, 147-159.

Færseth, R.B., Gabrielsen, R.H., Hurich, C.A., 1995. Influence of basement in structuring of the North Sea basin, offshore southwest Norway. Nor. Geol. Tidsskr. 75, 105-119.

Færseth, R.B., Macintyre, R.M., Naterstad, J., 1976. Mesozoic alkaline dykes in the Sunnhordland Region, western Norway: ages, geochemistry and regional significance. Lithos 9, 331335.

Gathe, R., Andersen, T.B., 1996. Extensional structures below the Jotun Nappe in Central south Norway; an example from the Lærdal area. Abstract Volume, Nordisk Geologisk Vintermöte, Åbo.

Gee, D.G., 1988. Thrust tectonics in the Scandes - upper crustal extension during Scandean compression. Geol. Foren. Stockholm Forh. 110, 390-392.

Gee, D.G., Guezou, J.-C., Roberts, D., Wolff, F.C., 1985. The central-southern part of the Scandinavian Caledonides. In: Gee, D.G., Sturt, B.A. (Eds.), The Caledonide Orogen: Scandinavia and Related Areas. J. Wiley, Chichester, pp. 109-133.

Gee, D.G., Lobkowicz, M., Singh, S., 1994. Late Caledonian extension in the Scandinavian Caledonides - the Røragen Detachment revisited. Tectonophysics 231, 139-155.

Gilotti, J.A., 1994. Eclogites and related high-pressure rocks from North-East Greenland. Rapp. Grønl. Geol. Unders. 162, 77-90.

Goldschmidt, V.M., 1912. Die kaledonische Deformation der süd-norwegischen Urgebirgstafel. Skr. Vidensk. Selsk., Christiania 19, $11 \mathrm{pp}$.

Griffin, W.L., 1987. 'On the eclogites of Norway' - 65 years later. Mineral. Mag. 51, 333-343.

Haremo, P., 1987. Stratigrafi og deformasjon i en KambroOrdovisisk lagrekke i Kaledonidefronten på Hardangervidda. Cand. Sci. Thesis, Univ. of Oslo.

Hartz, E., 1998. Late orogenic evolution of the East Greenland and Scandinavian Caledonides. Dr. Sci. Thesis, Univ. of Oslo.

Hartz, E., Andresen, A., 1995. Caledonian sole thrust of central East Greenland: A crustal-scale Devonian extensional detachment?. Geology 23, 637-640.

Hodges, K.V., Burchfield, B.C., Royden, L.H., Chen, Z., Liu, Y., 1993. The metamorphic signature of contemporaneous extension and shortening in the central Himalayan orogen: Data from the Nyalam transect, southern Tibet. J. Metamorph. Geol. 11, 721-737.

Hossack, J.R., 1984. The geometry of listric faults in the Devonian basins of Sunnfjord W Norway. J. Geol. Soc. London 141, 629-637.
Hossack, J.R., Garton, M.R., Nickelsen, R.P., 1985. The geological section from the foreland up to the Jotun thrust in the Valdres area, south Norway. In: Gee, D.G., Sturt, B.A. (Eds.), The Caledonide Orogen: Scandinavia and Related Areas. J. Wiley, Chichester, pp. 443-456.

Hveding, B.S., 1992. En strukturgeologisk unders $\varnothing$ kelse av mylonittsonen under Dalsfjordforkastningen i Atløy-Askvoll området Sunnfjord. Unpubl. Cand. Sci. Thesis, Univ. of Oslo.

Hurich, C.A., Kristoffersen, Y., 1988. Deep structure of the Caledonide orogen in southern Norway: new evidence from marine seismic reflection profiling. Nor. Geol. Unders. Spec. Publ. 3, 96-101.

Hurich, C.A., Palm, H., Dyrelius, D., Kristoffersen, Y., 1989. Deformation of the Baltic continental crust: views from seismic reflection data. Geology 17, 423-425.

Jamtveit, B., 1987. Metamorphic evolution of the Eiksundal eclogite complex, Western Norway, and some tectonic implications. Contrib. Mineral. Petrol. 95, 82-99.

Kullerud, L., Tørudbakken, B.O., Ilebekk, S., 1986. A compilation of radiometric age determinations from Western Gneiss Region, South Norway. Nor. Geol. Unders. Bull. 406, 277286.

Krogh, E.J., 1980. Geochemistry and petrology of glaucophane bearing eclogites and associated rocks from Sunnfjord, western Norway. Lithos 13, 355-380.

McClay, K.R., Norton, M.G., Coney, P., Davis, G.H., 1986. Collapse of the Caledonian Orogen and the Old Red Sandstone. Nature 323, 147-149.

Milnes, A.G., Koestler, A.G., 1985. Geological structure of Jotunheimen, southern Norway. (Sognefjell-Valdres section). In: Gee, D.G., Sturt, B.A. (Eds.), The Caledonide Orogen: Scandinavia and Related Areas. J. Wiley, Chichester, pp. 457-474.

Milnes, A.G., Dietler, T.N., Koestler, A.G., 1988. The Sognefjorden north shore $\log$ - a $25 \mathrm{~km}$ depth section through Caledonized basement in western Norway. Nor. Geol. Unders. Spec. Publ. 3, 114-121.

Morley, C.K., 1986a. Vertical variations in the Osen-Røa thrust sheet, North-western Oslo fjord, Norway. J. Struct. Geol. 8, 621-632.

Morley, C.K., 1986b. The Caledonian thrust front and palinspastic restorations in southern Norwegian Caledonides. J. Struct. Geol. 8, 753-765.

Nilsen, T.H., 1968. The relationship of sedimentation to tectonics in the Solund district of southwestern Norway. Nor. Geol. Unders. Bull. 292, 1-20.

Nilsen, O., Wolf, F.C., 1989. Berggrunnskart Røros og Sveg $1: 250,000$. Norges Geologiske Undersøkelse.

Norton, M.G., 1986. Late Caledonian extension in western Norway: A response to extreme crustal thickening. Tectonics 5, 195-204.

Norton, M.G., 1987. The Nordfjord-Sogn Detachment, W Norway. Nor. Geol. Tidsskr. 67, 93-106.

Osmundsen, P.T., 1990. Tektonostratigrafi of strukturell utvikling, Staveneset, Sunnfjord. Cand. Sci. Thesis, Univ. of Oslo.

Osmundsen, P.T., 1996. Late-orogenic structural geology and Devonian basin formation in western Norway: A study from 
the hanging wall of the Nordfjord-Sogn Detachment in the Sunnfjord Region. Dr. Sci. Thesis, Univ. of Oslo.

Osmundsen, P.T., Andersen, T.B., 1994. Caledonian compressional and late orogenic extensional deformation in the Staveneset area Sunnfjord, Western Norway. J. Struct. Geol. 16, 1385-1401.

Osmundsen, P.T., Andersen, T.B., Markussen, S., Svendby, A.K., 1998. Tectonics and sedimentation in the hanging wall of a major extensional detachment: the Kvamshesten Devonian Basin, Western Norway. Basin Res., submitted.

Palm, H., Gee, D.G., Dyrelius, D., Björklund, L., 1991. A reflection seismic image of Caledonian structure in central Sweden. Sver. Geol. Unders. Ser. Ca 75, 1-36.

Platt, J.P., 1993. Exhumation of high-pressure rocks: a review of concepts and processes. Terra Nova 5, 119-133.

Platt, J.P., England, P., 1994. Convective removal of lithosphere beneath mountain belts: Thermal and mechanical consequences. Am. J. Sci. 293, 307-336.

Richardson, S.W., England, P.C., 1979. Metamorphic consequences of crustal eclogite production in overthrust orogenic zones. Earth Planet. Sci. Lett. 42, 183-190.

Roberts, D., Gee, D.G., 1985. An introduction to the structure of the Scandinavian Caledonides. In: Gee, D.G., Sturt, B.A. (Eds.), The Caledonide Orogen: Scandinavia and Related Areas. J. Wiley, Chichester, pp. 55-68.

Rykkelid, E., Andresen, A., 1994. Late Caledonian extension in the Ofoten area, northern Norway. Tectonophysics 231, 157169.

Searle, M.P., 1995. Timing and rates of motion on thrusts, normal faults and strike-slip faults in Himalaya, Karakoram and Tibet. Terra Nova, Abstr. Vol. 7, 43.

Séguret, M., Séranne, M., Chauvet, A., Brunel, M., 1989. Collapse basin: A new type of extensional sedimentary basin from the Devonian of Norway. Geology 17, 127-130.

Séranne, M., 1988. Tectonique des bassins Dévoniens de Norvège: Mise en évidence de bassins sédimentaires en extension formés par amincissement d'une croûte orogenique epaissie. Thèse de doctorat, Academie de Montpellier.

Séranne, M., 1992. Late Palaeozoic kinematics of the MøreTrøndelag Fault Zone and adjacent areas, central Norway. Nor. Geol. Tidsskr. 72, 141-158.

Séranne, M., Séguret, M., 1987. The Devonian basins of western Norway: tectonics and kinematics of an extending crust. In: Coward, M.P., Dewey J.F., Hancock, P.L. (Eds.), Continental Extensional Tectonics. Geol. Soc. London, Spec. Publ. 28, 537-548.

Sigmond, E.M.O., Gustavson, M., Roberts, D., 1984. Berggrunnskart over Norge, M 1:1 million. Norges Geologiske Undersøkelse.

Sjöström, H., Bergman, S., 1989. Asymmetric extension and Devonian (?) normal faulting; examples from the Caledonides of eastern Trøndelag and western Jämtland. Geol. Foren. Stockholm Forh. 111, 407-410.

Sjöström, H., Bergman, S., Sokoutis, D., 1991. Nappe geometry, basement structure and normal faulting in the central Scandinavian Caledonides: kinematic implications. Geol. Foren. Stockholm Forh. 113, 265-269.
Sjöström, H., Bergman, S., 1994. Contraction and lateral extension in the Caledonian orogenic wedge of central Scandinavia: Evidence from a segment of the Seve-Köli terrane boundary. Abstr. Vol., Nordisk Geologisk Vintermöte, Luleå, 186.

Skogseid, J., 1994. Dimensions of the Late CretaceousPaleocene Northeast Atlantic rift derived from Cenozoic subsidence. Tectonophysics 240, 225-247.

Smith, D.C., 1984. Coesite in clinopyroxene in the Caledonides and its implications for geodynamics. Nature 310, 641-644.

Smithson, S.B., Ramberg, I.B., Grønlie, G., 1974. Gravity interpretation of the Jotun Nappe of the Norwegian Caledonides. Tectonophysics 22, 205-222.

Steel, R.J., Gloppen, T.G., 1980. Late Caledonian (Devonian) basin formation, western Norway: signs of strike-slip tectonics during infilling. Spec. Publ. Int. Assoc. Sedimentol. 4, 79-103.

Strachan, R.A., 1994. Evidence in North-East Greenland for Late Silurian-Early Devonian regional extension during the Caledonian orogeny. Geology 22, 913-916.

Swensson, E., Andersen, T.B., 1991. Contact relationships between the 'Askvoll group' and basement gneisses of the Western Gneiss Region (WGR), Sunnfjord, Western Norway. Nor. Geol. Tidsskr. 71, 15-27.

Tapponnier, P., Leloup, P.H., Lacassin, R., Harrison, T.M., Wenji, C., Ryerson, F., 1995. Diachronic uplift, transtension and sinistral shear rate along the Red River zone. Terra Nova, Abstr. Vol. 7, 43.

Torsvik, T.H., Sturt, B.A., Ramsay, D.M., Vetti, V.V., 1987. The tectono-magnetic signature of the Old Red Sandstone and Pre-Devonian strata in the Håsteinen area, western Norway, and the implications for the later stages of the Caledonian Orogeny. Tectonics 6, 305-332.

Torsvik, T.H., Sturt, B.A., Swensson, E., Andersen, T.B., Dewey, J.F., 1992. Palaeomagnetic dating of fault rocks: Evidence for Permian and Mesozoic movements along the Dalsfjord Fault, Western Norway. Geophys. J. Int. 109, 565-580.

Torsvik, T.H., Smethurst, M.A., Meert, J.G., Van der Voo, R., McKerrow, W.S., Brasier, M.D., Sturt, B.A., Walderhaug, H.J., 1996. Continental break-up and collision in the Neoproterozoic and Palaeozoic - A tale of Baltica and Laurentia. Earth Sci. Rev. 40, 229-258.

Torsvik, T.H., Andersen, T.B., Eide, E.A., Walderhaug, H.J., 1997. The age and tectonic significance of dolerite dykes in western Norway. J. Geol. Soc. London 154, 961-973.

Tucker, R.D., McKerrow, W.S., 1995. Early Palaeozoic chronology: a review in light of new U-Pb zircon ages from Newfoundland and Britain. Can. J. Earth Sci. 32, 368-379.

Wernicke, B., 1992. Cenozoic extensional tectonics of the U.S. Cordillera. In: Burchfield, B.C., Lipman, P.W., Zorback, M.L. (Eds.), Geology of North America, Vol. G-3, The Cordilleran Orogen: Conterminous U.S. The Geological Society of America, Boulder, CO, pp. 553-581.

Wilks, W.J., Cuthbert, S.J., 1994. The evolution of the Hornelen Basin detachment system, western Norway: implications for the style of late orogenic extension in the southern Scandinavian Caledonides. Tectonophysics 238, 1-30.

Ziegler, P.A., 1988. Evolution of the Arctic-North Atlantic and the Western Tethys. Am. Assoc. Pet. Geol. Mem. 43, 198 pp. 